\title{
Urban contrast of two cities from globalization. Gentrification, socio-cultural and economic aspects in Mexico and Valencia
}

\author{
María Guadalupe Valiñas Varela, Arturo España Caballero \\ Escuela Superior de Ingeniería y Arquitectura ESIA Tecamachalco. \\ Instituto Politécnico Nacional IPN. Naucalpan, Estado de México. Mexico \\ E-mail: arquinova@hotmail.com
}

\begin{abstract}
Globalization at present influences the transformation of cities in a similar way, they develop changes in their composition, related to socio-cultural and economic aspects that converge in cases of gentrification where the right to the city is altered, modifying the social, economic structure, And politics of the place, in addition to generating cultural changes according to processes related to postmodernity and current neoliberal policies that generate diverse negative changes such as the displacement of the original settlers, that is to say, a rupture of the social structure; Changes in soil values, which increase disproportionately making inaccessible and non-conservable properties for the inhabitants of lower purchasing power. However, this phenomenon also presents positive consequences such as revitalization and improvement of spaces, becoming in some cases in places offashion, or with great tourist importance and cultural diversity. This work shows a contrast of situations, forms and processes of two cities in different continent and with different characteristics with many similarities, as is the case of Mexico City in areas designated as the historic center, in its four quadrants: Atzacoalco, Cuepopan, Moyotla and Teopan, as well as the Polanco, Juárez, Doctores, Roma and Granada colonies, in contrast to the historic center and the districts of the city of Valencia such as Ensanche, Russafa, and Cabanyal among others. What is relevant is to generate a contrast identifying similarities and differences in the processes of urban transformation in two cities with different temporal space characteristics, but both immersed in current processes of migration and globalization in their territories.
\end{abstract}

Keywords: Gentrification, socio-cultural urbanization, globalization, postmodernity, land value, surplus value, urban imaginary

\section{Introduction}

In recent decades there has been a dispute over the central floor for urban recycling in which in some cases it is intended the overwhelming construction of works of great magnitude, among which are imposing buildings and modern shopping centers, spaces for trade And represent new socio-cultural practices, that is, a new way of life, where the flag of consumption exerts its main force. Individuals are attracted by symbolisms related to money and fantasy to belong to an important socio- economic status, nonconsciously, their spatial and sociocultural behavior is modified, but this in turn strengthens the economic growth and positioning of various transnational corporations.

This has resulted in changes in the environment, in terms of housing, land value, and use; Changes that end up generating an urban change, which makes homogeneous communities in heterogeneous societies, making progress, which deteriorates existing communities in the place where these spaces are established, and drives economic development 
and trade through change To proceed from the subject in its spatiality through consciousness.

Different situations are generated such as: social leakage and gentrification, that is, the inhabitants with lower economic resources sell their damaged homes and go to the peripheries, arriving new inhabitants with a greater purchasing power and with new ideologies and ways of thinking that displaced originals.

It can be emphasized that this fact, generates development and progress, although it ends with communities, giving way to new societies immersed in globalization.

There are strong socio-cultural and urban changes, as a result of the phenomenon: the land changes ownership and passes into the hands of large real estate, build buildings, demand for new housing is generated, without considering that infrastructure is insufficient because it was not planned and this produces Various problems of an urban but also social and cultural nature where it is necessary to solve different aspects quickly and with an adequate planning that is based on an equitable city right.

The main objective is to evaluate through a complex model the different effects of globalization involved with urban recycling for the construction of commercial spaces, in terms of housing, surplus value ${ }^{1}$, gentrification and socio-cultural changes. Studying the urban imaginary by means of spatial readings of the new and original inhabitants of the different places.

Secondary objectives:

1.To explain cases of urban recycling for the construction and use of various commercial spaces analyzing changes of social filtration, gentrification, economic and socio-cultural aspects.

2.Apply Semiotics to identify changes by means of signs.

3.Apply a complex thinking that relates several parameter theories to observe the different zones and the different urban imaginaries.

4.Know and prepare reports of different areas of Mexico City where urban recycling is given for the construction of commercial spaces and contrast it with the case of Valencia in Spain.
The justification of the subject is based on the importance and the boom that has been the search for central spaces destined to commercial activities in the last years being a phenomenon related to the actuality, the globalization and characteristic of the historical stage that we live that is immersed the Capitalism and postmodernity ${ }^{2}$.

The hypothetical assumption that globalization generates in cities with different characteristics, population movements that displace the original inhabitants of the central zones that are in dispute, increasing their value and surplus value, besides modifying their use, and Although there is an improvement and revitalization of the space, also generates a social rupture of existing neighborhoods and communities.

Due to the fact that there are already buildings in the central places, there is an urban recycling, which affects, in some cases, even buildings of historical and patrimonial value to give rise to these significant constructions that modify the way of life and the perception of the space, generating economic, social and sociocultural changes, which in turn modify the urban environment, undermining the existence of communities and neighborhoods, and favoring neoliberal policies, where the economic factor to raise capital of foreign companies prevails and is the one that designs city. The right to it is diminished and privatized.

The search for a balance that generates equity in the city with opportunities for economic development for all and respects the architectural and historical heritage must be a principle in Architecture and Urbanism

\section{Theoretical Bases}

The concept of gentrification was first coined in Britain after the end of World War II, with a postwar reconstruction in London predominating; Was Ruth Glass in 1964, a Marxist refugee from Nazi Germany, a pioneer of urban sociology in Europe, who began to use it (Lees, 2007: 4). Observing a displacement of the working class forced by the middle classes that implicitly implied an improvement of the neighborhoods and that 
referred strong conflicts, from threats to violent acts where the inhabitants were forced to leave their house, regardless of whether it was their own or Rent, establishing a social struggle with the displaced. Tom Slater relates that he went through this situation, when he was displaced in 1998 from his rented house in Tooting, south of London (Lees, 2007).

However, the process of gentrification is not analogous to its beginning, since it has gradually transformed, passing through different stages:

1): In the 1960s, it was presented as a sporadic production on a neighborhood scale, under the premise of combating urban decay.

2): From the 1980s to the mid-1990s, it is promoted by public-private partnerships in which there are intense social conflicts emanating from displacement.

3): At present it is observed both in the center and in the peripheries, with more flexible credit instruments in which supply and demand actively participate, presenting a marginalization of anti-gentrification movements. (López Morales, 2009)

Therefore, there is variation in the definition of the concept by various authors, as this process evolves little by little. A representative definition was formulated by Herbert Marcuse citing the following:

"Gentrification occurs when new residentswho disproportionately are young, white, professional, technical, and managerial workers with higher education and income levels-replace older residents-who disproportionately are low-income, workingclass and poor, And elderly-from older and previously deteriorated inner-city housing in a spatially concentrated manner, that is, to a degree differing substantially from the general level of change in the community or region as a whole. The definition hinges on economic, social, and population changes that cause physical changes to the neighborhoods. (Marcuse, 1985: 198-199)"3.

This process is related in some cases to return to the center, as Enrique Pérez Campuzano mentions when talking about residential mobility in central areas where the questioning: ¿between segregation and gentrification? (Coulumb, 2016: 29). The subject can also present debate in different aspects because it can be based on an urban regeneration of the centers as mentioned by Cesar Jiménez Alcañiz where he talks about the incorporation of sustainability criteria in historic cities and the case of Russafa in Valencia (Balandrano, 2016: 19)

The appearances of large commercial spaces according to the dimensions of the city are closely related to the theme of globalization, postmodernity and gentrification as can be seen in the section of Tena Núñez where he alludes to the Shopping Urbanization. The new cultural industries and their complex urban order defining it as follows:

It is a new type of cultural industry: the Shopping. These are the patterns of urbanization imposed by the emergence and development of the last generation of shopping malls: they are new urban-architectural spaces that revalue the public / private dichotomies and commerce / entertainment, displacing their main character from the sphere Economic to cultural, where the massive generation of "ghostly" impressions intensifies, social practices are promoted that respond to hyperreal forms of entertainment and a prototype actor (light people), achieving a new form of organization and urban experience: Shopping Urbanization (Tena, 2007)

The above generates gentrification aspect which is important to mention, however, converge many other elements as you can see below:

Gentrification is a framework of demographic, economic, political, cultural, imaginary and symbolic dimensions; however, attention must be paid to the relationship between the arrival and displacement of individuals, social practices and economic activities (Hernández, 2016: 43). The negative of the gentfication lies as Gaja mentions in the city of the exclusion of social dualization, if we continue in neoliberal austerity, further accentuating social polarization.(Gaja 2016:97)

\section{Methodology}

The methodology is based on the elaboration of a complex model from the thought of Edgar 
Morin; with all the approaches that can be crossed on the basis of an open rationality how the same raises it in his book "Introduction to the Complex Thought" where it approaches a perspective that contemplates the phenomenal world, making a weave of inseparable associates, theories that will leave Linking as if it were a tissue (complexus: what is woven together) of heterogeneous constituents inseparably associated: it presents the paradox of the one and the multiple (Morín, 1998: 137), where it will be contrasted, with the semiotic visual, Where it starts from the concept of space-meaning, where reality materializes reality, from the consciousness and is analyzed with signs on several levels of referent: ontic, ontological, pragmatic, aesthetic and semantic.

Complex model that includes:

I Compilation of variables:

Socio-economic: Income, occupations, commercial values, commercial spaces: land use, social filtration, gentrification.

Urban space: morphology, land uses, density, monuments, equipment.

Cultural partners. Semiotics The subject, space-consciousness, symbols that modify his behavior and the symbolic cultural aspect

II Processing of information

Establish a valuation system.

1.-Economic partner

1.1 Economic analysis, soil values, exchange analysis and surplus value.

1.2 Real Estate Developers

2.-Urban space

2.1 Density, social filtration and Gentrification

2.2 Morphology

2.3 Land use and change

3.-Semiotic and phenomenological study

3.1 The interdisciplinary study of city and city, deepening; In physical space and territory, as well as socio-cultural characteristics of society and communities.

4.-Strategic Planning

4.1 Urban diagnosis

4.2 Prospective

\section{Measurement and analysis}

To obtain data, interviews and questionnaires were applied to students and professors in the career and postgraduate of Architecture and Urbanism, as well as interviews with inhabitants and key actors in both cities. Different databases were used, such as the National Institute of Statistics, Geography and Informatics, INEGI in Mexico and its equivalent in Spain, the National Institute of Statistics INE in addition to the Valencian Institute of Building, IVE and the Statistical Portal of the Generalitat Valenciana, obtaining the following analysis data:

Mexico City, formerly known as the Federal District, has an area of 1495 square kilometers and is the capital of the country, has a population of 8.9 million inhabitants, but if the metropolitan area is considered as 21 million inhabitants, it is one of the most populous and large populations in the world, is a global city that functions as a business center. The city of Valencia is also a global city and business center, but of smaller scale and in addition is a coastal city; Has a dimension of 134, 6 square kilometers, has 790201 inhabitants that amounts to 2544264 inhabitants (INE, 2016) if we include its conurbation, is the third and most populated area of Spain, after Madrid and Barcelona. Therefore, the dimensions of both cities are totally different as well as the number of inhabitants and their characteristics, this work aims to find similar aspects related to gentrification despite their wide differences.

According to the Compilation of the variables

In Socio-economic: Revenues, occupations, commercial values, commercial spaces: land use, social filtration, and gentrification we can mention the following: the National Minimum Wages Commission in Mexico through resolution published in the Official Gazette of the Federation of December 19, 2016, effective as of January 1, 2017, resolved the minimum wage for $\$ 80.04$ pesos national currency or 1920 pesos per month, however, according to the economic report of Mexico City of 2016, Daily salary of contribution to the IMSS was 412.79 pesos per day, which increases to 9900 pesos per month. (Sedeco 2016) However, in Spain according to the data page macroro (Expansion 2017), the minimum wage for 2017 is 825,7 euros per month that in pesos 
would mean 16700 pesos. According to the statistical portal (Generalitat Valenciana 2017) are around 10400 to 14600 euros per year per capita. However, in the interviews carried out in Spain the most repetitive response was "we are in mileurismo", that is to say a thousand euros monthly, being the most common salary obtained in response; In the sample in Mexico was repeated the response of 4000 pesos and as you can see the salaries are not equivalent, nor even when making the change to pesos, since a thousand euros would be almost 23000 pesos, but it is important to mention that it is also not possible to buy The same things with the same amount of money in one country as in the other, in Spain things have a higher cost.

In employment-related matters in Mexico City, the total number of employed persons is $4,194,929$, according to data from the National Survey of Occupation and Employment (ENOE). The unemployed add up to 222 thousand 41 (Sedeco 2017). And of the 57.2\% represents informal trade.

In the city of Valencia according to the regional accounting of Spain base 2010 according to branches of activity in the National Classification of Economic Activities (NACE Rev.2) employment is governed as follows: Agriculture $8.1 \%$, extractive industries $11.9 \%$, manufacturing $12 \%$, construction $10.1 \%$, services $9.5 \%$, trade $10.8 \%$, information $5.5 \%$, financial activities $8.7 \%$, real estate activities $11.9 \%$, Technical and scientific professional activities $8.5 \%$, public administration $8.7 \%$, artistic activities $9.8 \%$. In the survey of active population EPA in 2017 1,944,600 people with work, 11,800 unemployed, and 479,200 unemployed. In the surveys it is very representative to hear in both countries about the economic crisis that occurred in the United States in 2008 where they were about to break several banks due to the excess of contracted mortgages, Spain was dragged in this process when bursting the housing bubble, where the construction stopped for several years and most of the debtors were not able to cover the mortgages, losing possession of their properties, which resulted in an oversupply of real estate by the banks and the fall in prices, besides not being possible the recovery of money. This is very important in terms of soil values in the area of urban space since in the process of gentrification these increase by passing the properties first by a deterioration, to be subsequently offered and renewed in their typology, increased in value, which would question if in Spain really happens the gentrification when giving the break of the

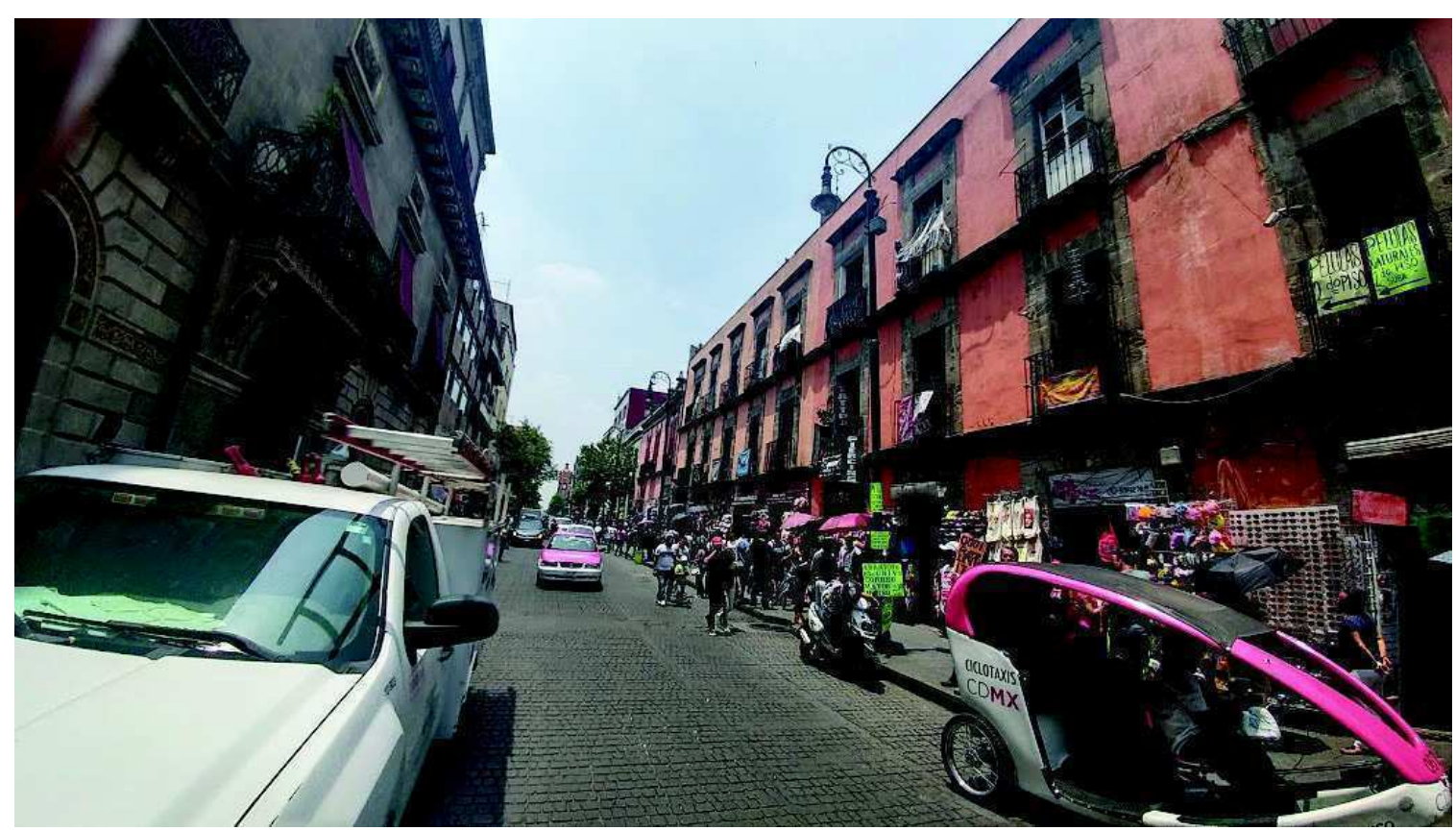

Figure 1.

Calle del Carmen in the Historic Center in Mexico with impaired properties 
Figure 2.

Cabanyal neighborhood in Valencia, traditional houses

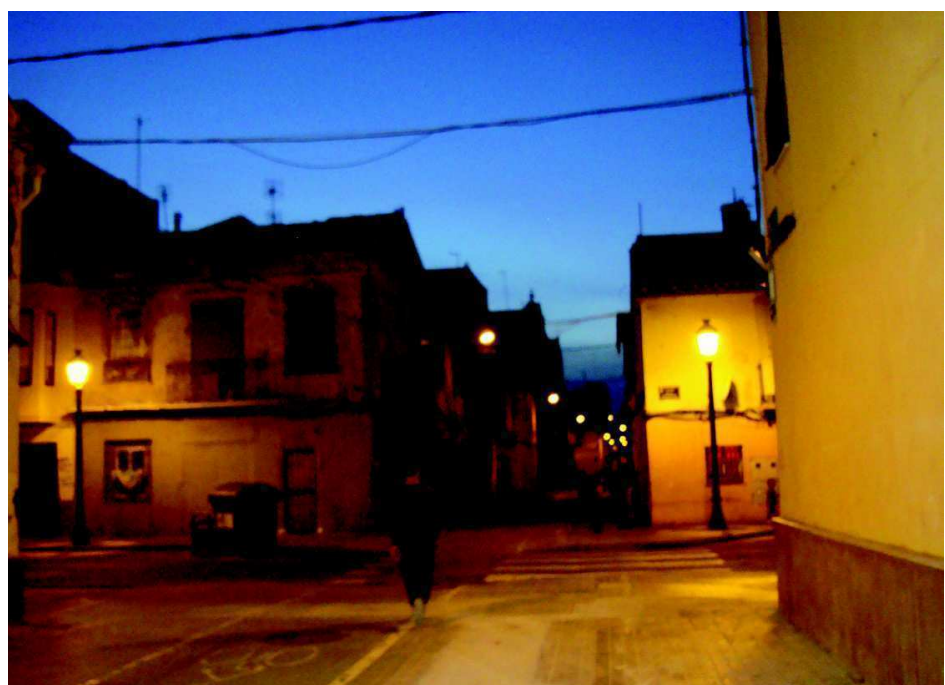

Figure 3.

Plaza 2000 Merced in Mexico raised as demolition in the rescue Project

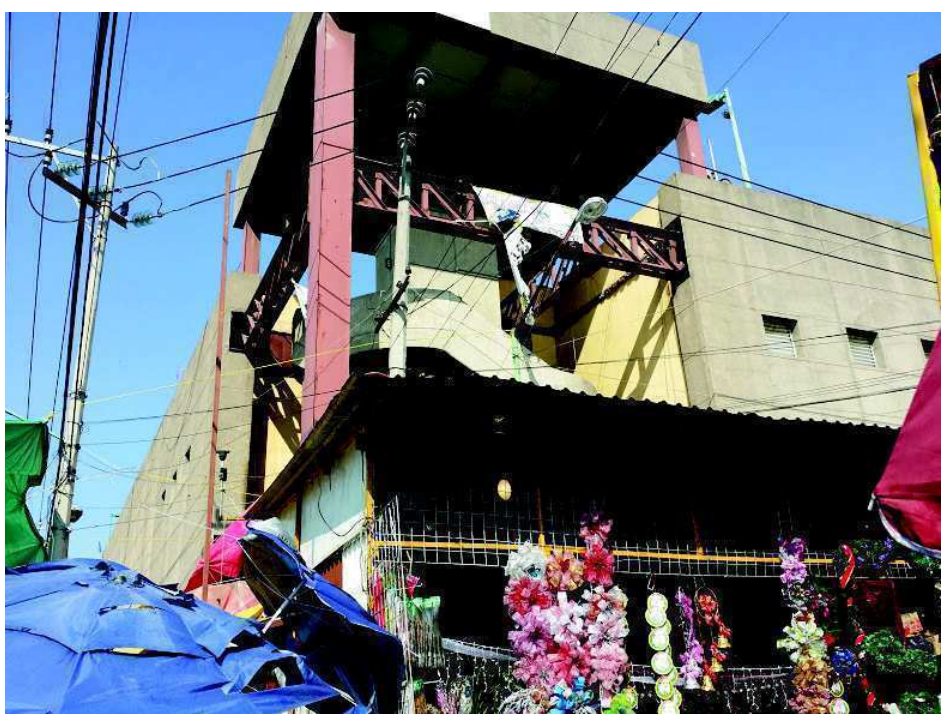

real estate bubble. In Mexico the buildings in the central areas are in a strong dispute as they are closer to the historical center where historical heritage buildings are invaluable with irregularity characteristics and many are deeply deteriorated, both in the center and in the outskirts of the city. Center and in colonies such as the Doctors, Juarez, Rome, and New Granada themselves that have been a reason for plundering for real estate developers and government actors, where they begin to approve systems of cooperation, which are agreements at their discretion Between private individuals and the authority that allows to relocate and to exchange uses, destinies and potentials of the ground, besides relotificar independent of the existing urban plans. In the surveys carried out in the Historical Center of Mexico, the inhabitants repeatedly refer to the expropriation of several plots that do not have documentation and which are later demolished for the construction of new buildings. (Figure $1)$.

In the surveys conducted in Valencia is recurrent the case of Cabanyal, where by making various routes can be seen land without construction where previously were thrown houses to give way to the expansion project of Avenida Blasco Ibáñez, pretending to turn it into a hotel zone Which at the moment is representative for its traditional houses of century XIX which are very deteriorated. The councilor of Valencian Culture, Gloria Tello in an interview mentions the importance of putting special attention in this area, which represents a deep cultural symbolism in the Valencian community. Similar situation occurs in the rescue project of the Merced in 
the Historic Center of Mexico City, where to realize a modern comprehensive project, the authorities forgot the traditional markets and its inhabitants and tenants, place of important cultural symbolism. In both cases the projects, although different because in the Cabanyal they are coastal houses (figure 2), and in the Merced of traditional markets, (figure 3) the same essence of a change of density in the zone is seen, where the Buildings of apartments, offices or hotels are the consequence of these majestic projects that can multiply the value of the ground by the number of floors and receive the tourism.

Another interesting case in Valencia is presented in the Ensanche, commonly known as the neighborhood of the bourgeoisie with the existence of the commercial center the "English Court", land where was formerly the Convent of St. Catherine of Siena, part of the historical memory And patrimonial of the place, that was destroyed at the same time that the zone increased of value and became one of the zones more elitized along with the Columbus Market (Figure 4) that changed its market function by a type of small commercial center. Resuming the project of rescue of the Merced in Mexico allows a glimpse of what it represents and means a traditional market in the conscience of the inhabitants.

And then referring to the cultural symbolic aspect from an optics of Semiotics and Phenomenology, all the interviewees were asked how they saw their city in the past, in the present and in the future where it can be referred to: order, disorder and uncertainty

\section{Conclusion}

The two cities in spite of their physical differences present similar cases in zones at different stages of the gentrification process, although we can say that this process has other aspects to which they were awarded in its beginnings, the government hand prevails in the proposal of Urban reforms with significant improvements in the quality of the public space, the renewal of the traditional population with the arrival of people from other geographical areas, a significant increase and renewal of commercial activity and the rise in prices in the real estate sector. In Valencia the shopping centers are associated with a bad practice that deteriorates the commerce of neighborhood and is not own of the place, also generates

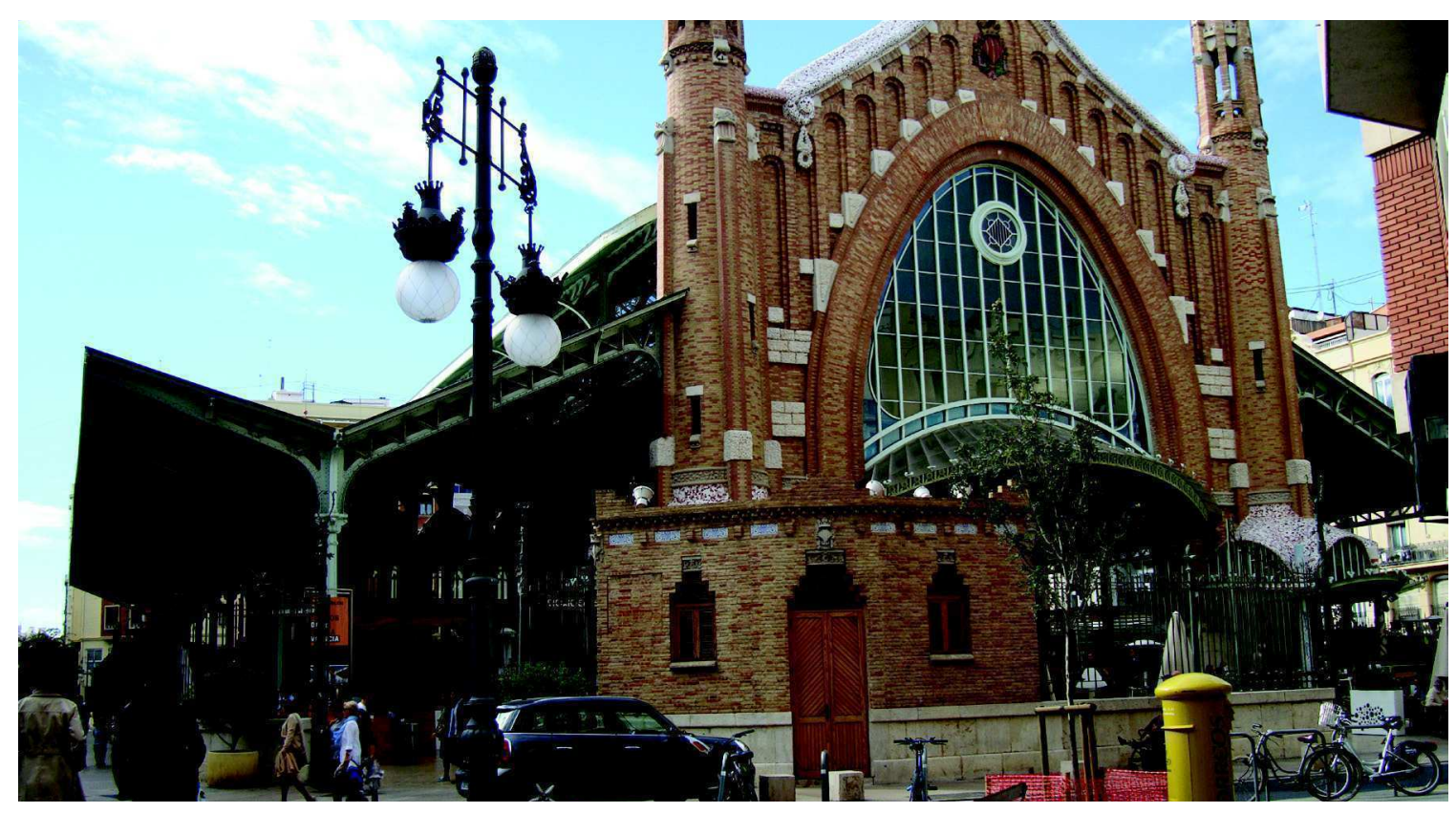

Figure 4.

Columbus Market (Mercado de Colón) in Valencia 
Figure 5.

Russafa neighborhood in Valencia

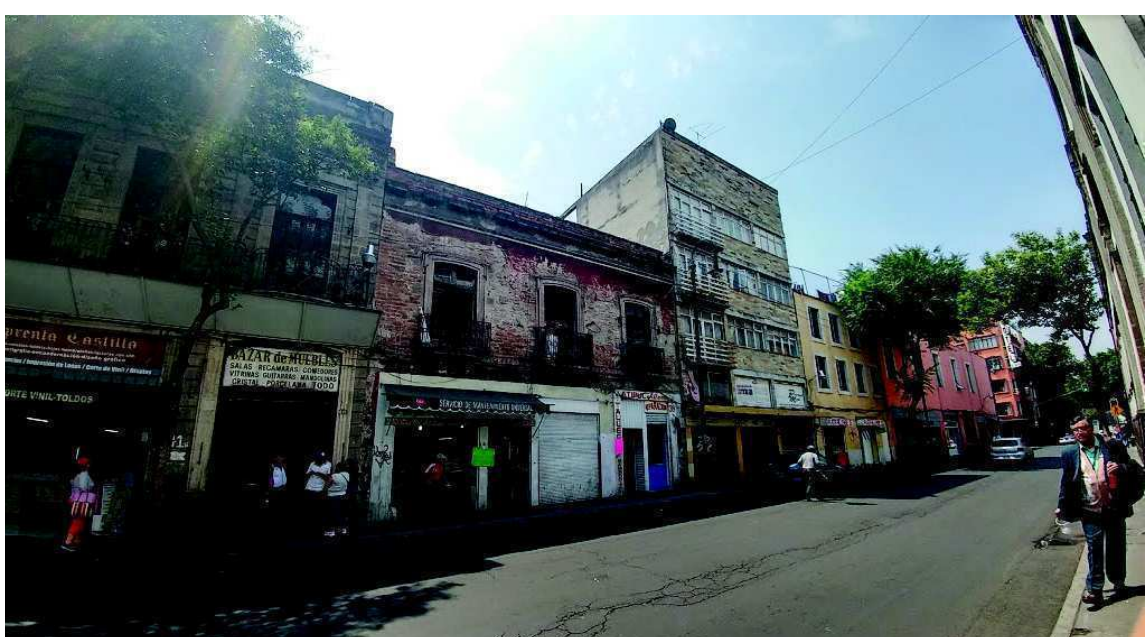

Figure 6.

Calle de Allende in the Historic Center of Mexico City

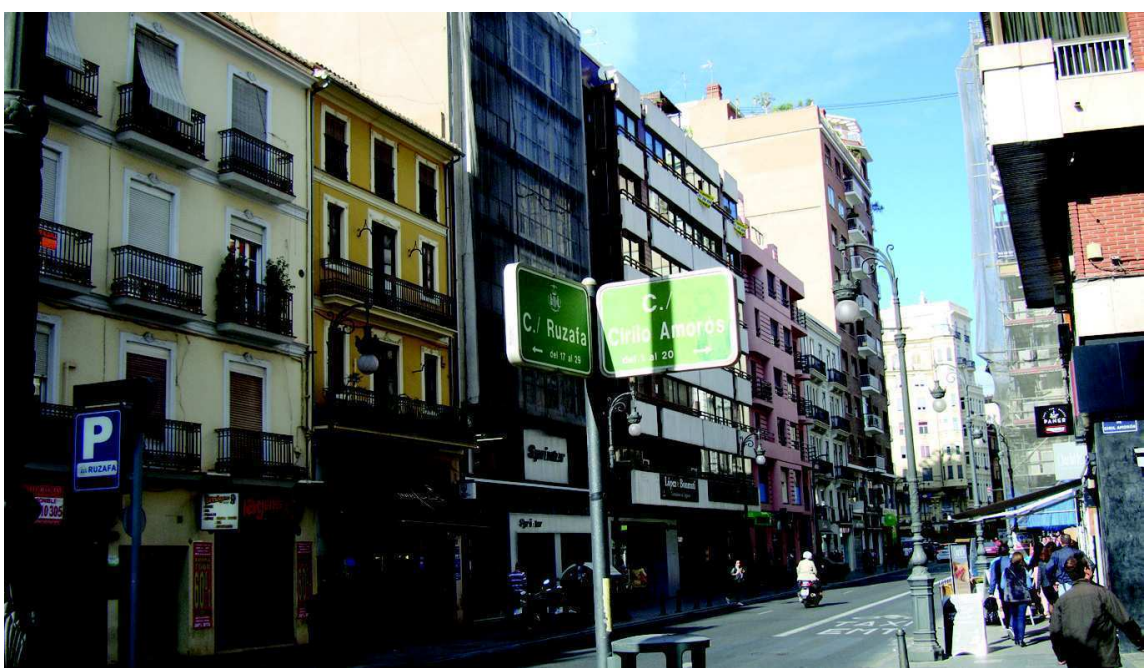

an unsustainable mobility. The historic center of Mexico City presents a strong problem of informal commerce, the government proposal to solve it is the relocation of these merchants in small commercial centers largely rehabilitated in historic and artistic heritage buildings.

In Mexico in addition to what is said of the Historic Center are also identified central colonies with important features in the process of gentrification such as the colony Doctors with the case of Tabacalera where the population was expelled by lies in the same colony, the dairies and the pulquerías, historical businesses, that have disappeared by the appearance of new neighbors and that at that time were very representative.

For the deterioration of an area this may be related even with natural disasters such as the earthquake of 1985 in Mexico that gave rise to the popular housing renovation program in central areas such as the Historic Center,
Colony Morelos, Doctors, Lorenzo Boturini, San Antonio Abad, among others, said program promoted a reconstruction of the colonies by expropriation of different buildings, granting facilities to tenants to become owners, however said program did not work as expected and many of the buildings entered In real estate speculation. The case of the overflow of the River Turia in the City of Valencia is also antecedent for the deterioration of zones like the Cabanyal, however, the established public policies have done their thing as they potentiate more the deterioration in these cases as established by Neil Smith in his Theory the rent gap "which contemplates a differential in current capitalized income and future income that can be achieved; That is, the potential profit generated for real estate developers where they are trying to devalue capitalized current income to the maximum and to appreciate the maximum potential rent in the future (López 
Morales, 2009). This effect is also present in the area of the Alameda in the Historic Center of Mexico City, regenerated and with a new presentation to tourism.

In Valencia, the neighborhood of Russafa (Figure 5) is mentioned repeatedly. This neighborhood became a problematic place in a fashionable neighborhood (Del Romero 2015). When you walk along its streets you can see the appearance of a large number of bars. Is nocturnal, similar situation happening in several points of the Historical center in Mexico as they are the street of Allende (Figure 6) and Donceles where the nightlife by means of canteens and bars has taken more force.

In both cases different phases are observed: gentrificated zones and zones in processes of gentrification and although the urban diagnosis draws a prospective of cities with similar problems that are product of global characteristics in the different territories and of population movements that entail an expulsion of the original population and replacement of the same, since the spaces are revitalized, becoming fashionable neighborhoods, tourism referents and with an increase of its value, the obligatory debate is if these processes are natural product of the postmodernity and if it will be possible to find a balance that favors the right of city and equity.

\section{Notes}

1 Increase in the value of a real estate, due to circumstances independent of any improvement made in it.

2 Postmodernism is a cultural process identified in the beginning of the 1970s, for Tena it is a very complex period because a wide range of urban processes and forms that dialogue with economy, communication and the environment emerge. (Tena Núñez 2007:207).

3 Marcuse bases this definition on that used by Daphne Spain, in Gentrification Score 3 AM. DEMOGRAPHICS 14 (1981), which considers "the movement of middle-class families in urban areas that cause property values to increase and have the side effect of expulsion from the poorest families."

\section{References}

Balandrano, Arturo; Valero Valeria y Ziccardi Alicia Camacho (2016) Conservación y desarrollo sustentable de Centros Históricos. Universidad Nacional Autónoma de México. UNAM

Camacho Cardona, Mario. (2006). Espacio Sémico Urbano-Arquitectónico. Ecuador Edit. UTPL (Universidad Técnica Particular de Loja) p. 115

Lees, Loretta, Tom Slater, Elvin Wily. (2007). Gentrification, New York, London, Taylor \& Francis

Coulomb René, Esquivel Hernandez Maria Teresa, Ponce Cernicharo Gabriela (2016) Habitar la centralidad urbana II Prácticas $\mathrm{y}$ representaciones sociales frente a las transformaciones de la Ciudad Central Instituto Belisario Dominguez México

Cuquerella, Toni (2017) El diario.es http:// www.eldiario.es/cv/economia/repuntardesocupados-Comunitat-ValencianaEPA_0_637636323.html (Consulting day June 5, 2017)

Del Romero Reanude, Luis; Lara Martín Laura (2015) De barrio-problema a barrio de moda: Gentrificación comercial en Russa-fa, el "Soho" valenciano Anales de Geografía vol. 35, núm. 1 187-212

Expansión, (2017) Aumenta el salario mínimo en España http://www.datosmacro.com/smi/ espana (Date of consultation June 5, 2017)

Gaja i Díaz Fernando (2016) Futuropolis. Entre la tecnoutopía y la ecodistopía. Colección Modelos para armar. España

Generalitat Valenciana.(2017) Portal estadístico http://www.pegv.gva.es/ temas/economia/cuentaseconomicas/ indicadorde larentafamiliar disponibleparaambitossubregionales (Consulting day, June 5, 2017)

Hernández Cordero, Adrián (2016) En transformación. Gentrificación en el Casc Antic de Barcelona. Universidad Nacional Autónoma de México UNAM

Instituto Nacional de Estadística. Contabilidad Regional de España. Base 2010. <http:// www.ine.es $>$ INEbase (Consulting day, June $5,2017)$ 
López Morales, Ernesto. "Gentrification de Loretta Lees, Tom Slater y Elvin Wyly”, en: Revista de Geografía Norte Grande, núm. 44, 2009,

Disponible en ehttp://www.redalyc.org/ pdf/300/30012208010.pdf (Consulting day, June 29, 2014)

Marcuse, Peter. "Gentrification, Abandonment, and Displacement: Connections, Causes, and Policy Responses in New York City", 28 Wash. U.J. Urb. \& Contemp. L. 195 (1985) http://digitalcommons.law.wustl.edu/ urbanlaw/vol28/iss $1 / 4$

Morín Edgar. (1998) Introducción al Pensamiento Complejo. Editorial Gedisa

Tena Núñez, Ricardo (2007) Ciudad cultura y urbanización sociocultural. Editorial Plaza y Valdés. México

Tena Núñez, Ricardo (2007) Shopping Urbanización. Las nuevas industrias culturales y su complejo orden urbano http:// www.eumed.net/libros-gratis/2011f/1131/ shopping_urbanizacion.html. (Consulting day October 20, 2014)

Sedeco, Reporte económico de la ciudad de México en el 2016. http://reporteeconomico. sedecodf.gob.mx/pdf/Resumen $\% 20 \mathrm{de} \% 20$ indicadores_tercer\%20trimestre $\% 202016$. pdf (Consulting day, June 5, 2017) 